\title{
Found! Restoring and Digitizing the Cuala Press Sample Book
}

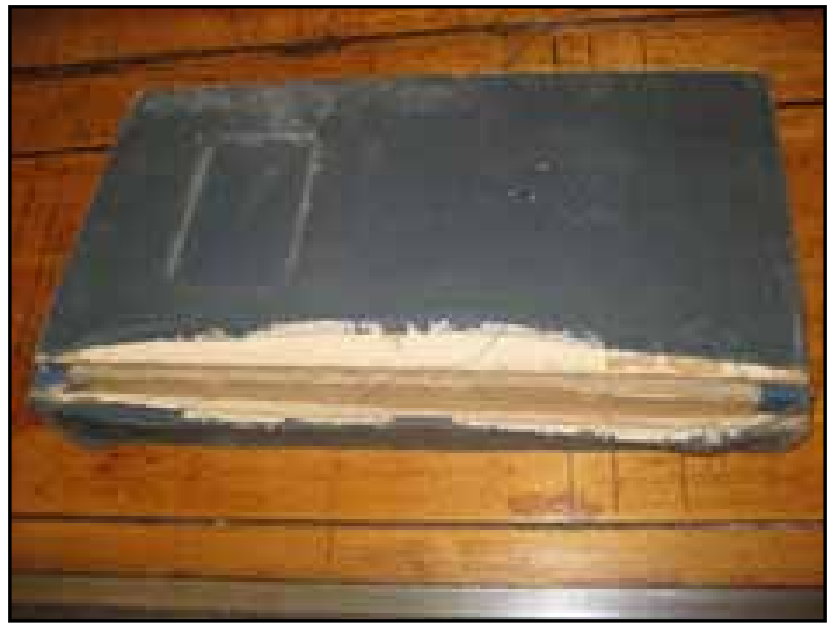

The Cuala Press sample book before restoration

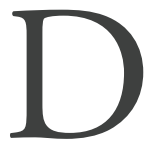
uring the summer of 2010 , a colleague brought me what appeared to be an old scrapbook. This scrapbook was in poor condition with a torn spine, worn cloth cover and acidic pages.

Inside this scrapbook (which I began calling a sample book) was an assortment of greeting cards from approximately 1908-1946, all printed by the Cuala Press. The Cuala Press (pronounced "coo-la") was an Irish industry that was begun by William Butler Yeats' two sisters: Elizabeth Corbett Yeats 1868-1940 (known as Lollie) and Susan Mary Yeats 1866-1949 (known as Lily). The Cuala Press began in a similar craftsman-focused way as William Morris' Arts and Crafts Movement in England: it even consulted with the printer who had studied with Morris (Emery Walker). The Cuala Press used the same printing fonts as Morris' Kelmscott Press and Lily Yeats was employed doing embroidery for Morris' Kelmscott House business for six years (Hardwick, 120). The Cuala Press was a largely Irish attempt at the Morris idea: Irish art and poetry, hand-set type which was letterpress printed and which was then handcolored by Irish artists (Lewis, 61). The press was part of a larger concern known as Cuala Industries which produced lace and embroidery, pottery, hand-printed books, greeting cards, hair brushes and mirrors. Cuala Industries was also a business managed and operated almost entirely by women. This sample book is a true time capsule of the Cuala Press' output. Photographs in the sample

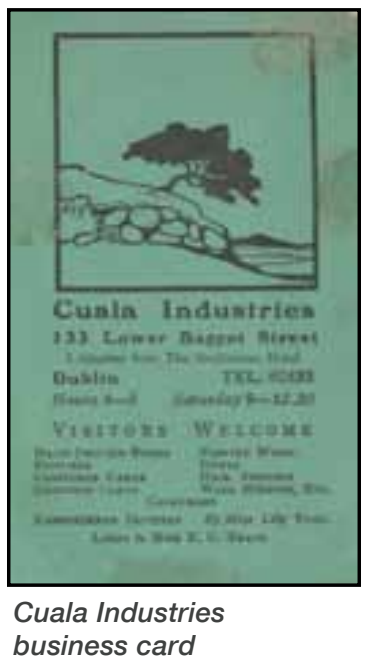

book show the Cuala Industries sales booth at an undated exhibition in Belfast.

The Cuala Press was a Yeats family enterprise with brothers William and Jack and Lily and Lollie all involved. William wrote books and poetry, Jack created illustrations and Lily and Lollie ran the press. The printed cards in the sample book are beautiful and mostly contain Irish sayings and poetry, some in Gaelic by poets such as Susan L. Mitchell, Katharine Tynan, Padraic Colum and W. B. Yeats. This was combined with art by an Irish artist. There are predominantly greeting cards, but there are also bookplates, programs, mundane items like business forms and booklets for anniversaries and holidays.

As Preservation Librarian at the Z. Smith Reynolds Library at Wake Forest University, I realized it was a great opportunity for a restoration project. I was also excited by the content of this sample book, which represented examples in chronological order of the production of the Cuala Press beginning in 1908. 
I wondered if anyone else has seen this sample book except possibly Dolmen Press owner, Liam Miller.

Some of the materials of the Cuala Press were donated to Trinity College, Dublin by the Yeats heirs and some stayed with the printing operation inherited by Liam Miller. I discussed the provenance of the sample book with former Rare Books Librarian at Z. Smith Reynolds Library, Richard Murdoch, but he was unsure of its purpose or how it came to the Dolmen Press. The Cuala Press had a primary period of production from 1908-1946. Printing was also done under the Cuala Press name during a revival period from 19691989 (Redshaw, 139). Somehow, this sample book was separated from the Dolmen Collection when it was processed in our library. Its discovery represented a unique piece which gave a glimpse into the Cuala Press, the kinds of things it printed and photos of their products.

The restoration project would involve two tracks: one to remove the cards and restore and reconstruct the binding; and another to scan the cards for a digitization project. Before we took any direct action, we photographed the entire book and produced an electronic version or "e-book" of the piece as it was. This provided an easy way to see and page through the book. It also provided a photographic record to use as we pieced the restored book back together. I hoped this e-book would allow access to the sample book by anyone from anywhere.

I began working with Carolyn Jones, a graduate student assistant, to remove the cards one by one. The cards were glued into the original book, so some of the paper lifted off with the cards as they were removed.
Often, after the cards were removed, large holes were left in the original pages because the paper stuck to the reverse side of the cards. Many of the cards contained ephemeral information (printing dates or number of copies printed.) which we wanted to preserve so we would not be gluing these cards back into the restored book. After removal from the acidic paper of the original book, each card was cleaned using a white eraser to remove any dirt or discolorations.

As the cards were removed, I made archival envelopes to protect the loose cards and to keep them in small batches for scanning. Because we had used our book scanner to create an electronic version of the Cuala Press sample book, we had a photographic verification of their original order. This record allowed us to safely remove these cards.

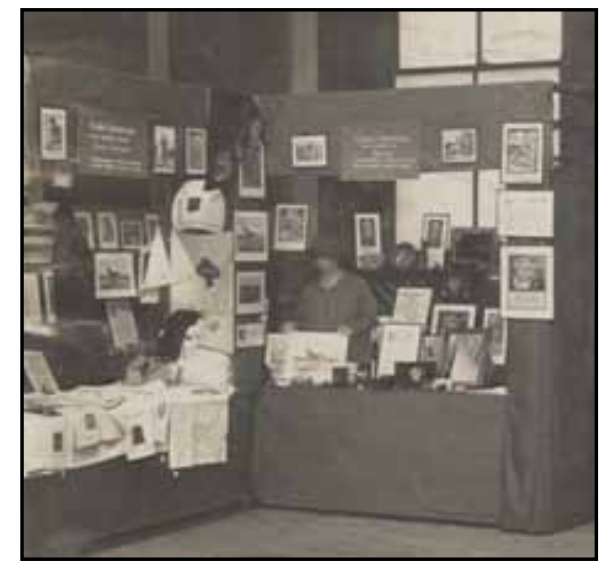

Cuala Industries booth at an undated Belfast exhibition

For the digitization portion of the project, we scanned each card at a 600 dpi resolution and stored these as TIFF images on a hard drive. The scanning part of the project used a Google spreadsheet, where each card was thoroughly described by adding descriptive metadata. This spreadsheet listed each card with as much information as we could collect: the artist, poet, size, image description, and stray or identifying marks, etc. The spreadsheet worked as a tracking mechanism for the progress of the project, so we could always gauge our progress. The spreadsheet served as a template to enter metadata fields into our institutional repository. When the scans were done, we uploaded both the scans and the metadata to our institutional repository. We then attached the metadata in the spreadsheet to each image and the metadata record was attached to each scan.

We were prevented from placing the digital version of the Cuala Press samplebook on theZ. Smith Reynolds Library web site (http://zsr.wfu.edu/ collections/digital/) with our other digitization projects by copyright. We own the Dolmen Press Collection materials, which is how we came to own a small amount of the Cuala Press materials as well. Liam Miller, the editor and owner of the Dolmen Press, protected the Cuala materials over the years, even preserving the individual printing plates. When Miller began the Dolmen Press, he acquired some Cuala Press materials which lived in his archive until the Dolmen Press Collection was purchased by Wake Forest University in 1987. The Dolmen Press Collection (http://wakespace.lib.wfu.edu/ xmlui/handle/10339/27836) was processed in 2004 and this allowed scholars to use this priceless treasure. However, it was not clear who retained copyright for the artistic and literary content of both the Dolmen and Cuala Press materials. In some cases, it was individual artists, writers and poets. In our case, we found the copyright-holder for the Yeats family (only one of the many contributors to the Cuala Press) is the Artist Rights Society (http://arsny.com/) 
an artistic and literary consortium in the US and United Kingdom. My library made a request to the Artist Rights Society to simply publish the sample book digitally on the ZSR Library website. The response from the holders of the copyright was to ask for an annual payment for making this e-book available, an offer we declined. My hope is that this material will eventually be accessible to anyone. Copyright is full of many caveats and pitfalls as an article in American Archivist by Maggie Dickinson recently pointed out. Our attempt to locate the copyright holder for the Cuala Press materials took several years. The Cuala Press materials contain the work of dozens of artists and poets, so this project could potentially involve a lifetime of searching for individual copyright holders, and then after all this searching, yield no accessible digital form.

For the preservation side of the project, I dis-bound the book (separated the text block from the cover boards) and discarded the text block. I retained the boards and planned to re-cover them with new book-cloth similar to the original. I ordered Canson Mi-Tientes paper which is made in $19 \times 25$ " sheets for the text block. These sheets were then cut and folded to the correct size. I sewed these signatures together at the same thickness of the original book, using Irish linen thread, of course!

I lined the spine with Irish linen. I ordered a Cialux book cloth similar in color and texture to the original, and re-covered the boards. I then reunited the newly-sewn text block with the boards.

The restoration project then was completed by placing the cards back inside the restored book using "SeeThru Mounting Corners" in their original position. These mounting corners are really hand-folded Mylar strips that attach only to the page and appear like very large photo corners. The mounting strips secured each card to the new pages of the book without any adhesive.

The cards now have a safe environment in which to live out their lives in a well-preserved, acid-free book. This was a very satisfying project because it combined two of my interests: hands-on preservation and digitization. From restoring the Cuala Press sample book, I learned to love the Irish art and poetry printed by the Cuala Press. I also learned about the problems of copyright on a complex level and was able to accept that the digital form of this project isn't ready for prime time just yet.

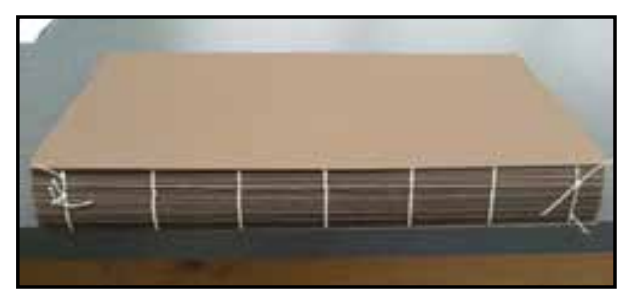

Newly sewn textblock

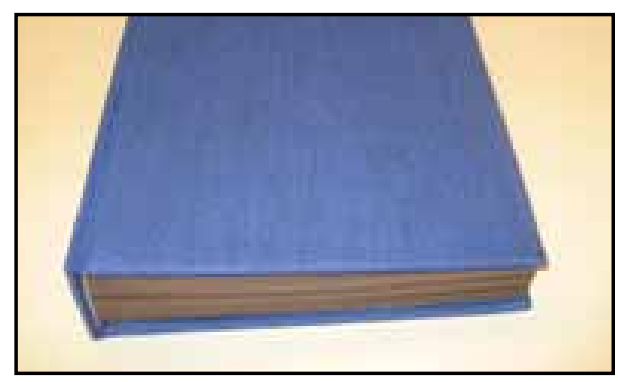

Restored sample book

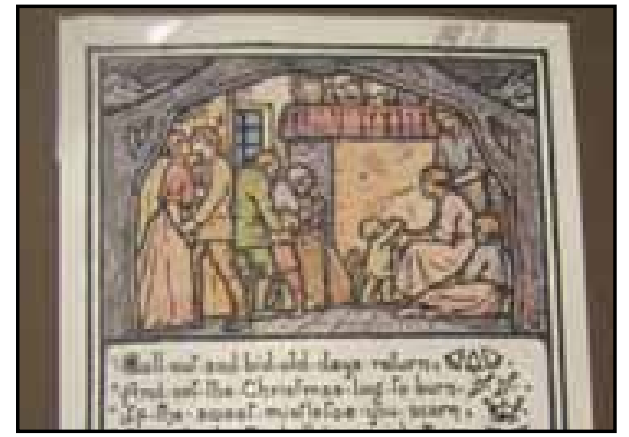

One of the Cuala Press cards

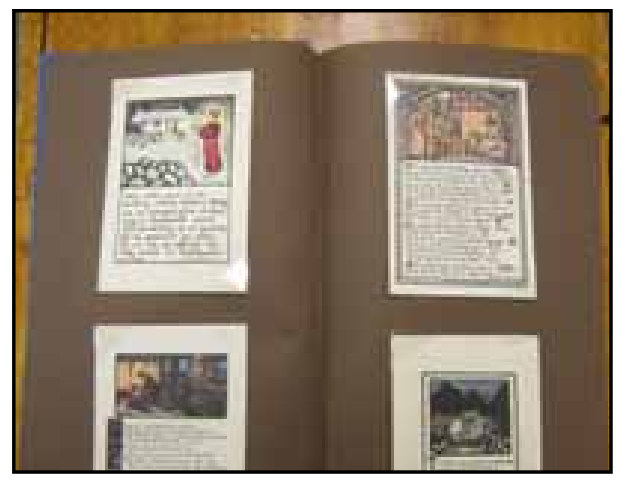

A page from the restored sample book

\section{Bibliography}

Dickinson, Maggie. "Due Diligence, Futile Effort: Copyright and the Digitization of the Thomas E. Watson Papers." The American Archivist 73 (Fall/Winter2010): 626-636.

Gatch, Milton McC. The Yeats Family and the Book Circa 1900. New York :The Grolier Club, 2000.

Hardwick, Joan. The Yeats Sisters, A Biography of Susan and Elizabeth Yeats. Glasgow: Harper Collins, 1996.

Lewis, Gifford. The Yeats Sisters and the Cuala. Dublin: Irish Academic Press, 1994.

Miller, Liam. The Dun Emer Press, Later the Cuala Press. Dublin: Dolmen Press, 1973.

Redshaw, Thomas Dillon. "Remains and Removals: The Cuala Press Revival" 1969-1989. The South Carolina

Review 43.1: 139-162. 